Capt. W. N. McClean. Capt. McClean's activity in the development of inland water survey in Great Britain is well known, and, in addition to the practical survey and record work, he initiated and organized the discussion on the need for this survey which the British Association staged at the York meeting in 1932. That discussion gave birth to the committees of the British Association and Institution of Civil Engineers, and these two bodies induced the Government to appoint the present Inland Water Survey Committee of the Ministry of Health. The graphical records of the Ness Basin rivers, which are similar to those published for the Aberdeenshire Dee, are the first of their type in Great Britain, and bring together the hydrological and meteorological records in a form from which statistical data may be derived or any desired analysis of river flow and storage may be made. A list of the published records can be obtained from "River Flow Records", Parliament Mansions, Victoria Street, S.W.1.

\section{American Society of Ichthyologists and Herpetologists}

$A x$ the twentieth annual meeting of the American Society of Ichthyologists and Herpetologists, held in Washington, D.C., on May 4-8, the following officers were elected : Honorary Presidents, John T. Nichols and Dr. Leonhard Stejneger; President, Prof. William K. Gregory ; Vice-Presidents, L. M. Klauber, Leonard P. Schultz, and Dr. Hobart M. Smith; Secretary, M. Graham Netting; Treasurer, Dr. Arthur W. Henn; Editor-in-Chief, Mrs. Helen T. Gaige, of Copeia; Ichthyological Editor, Lionel A. Walford; Herpetological Editor, Karl P. Schmidt. The election of four honorary foreign members was announced at the meeting; namely, for 1936, Prof. David M. S. Watson, University College, London, and Prof. Franz Werner, University of Vienna ; for 1937, Dr. Leo S. Berg, Academy of Sciences, Leningrad and Dr. W. Wolterstorff, Museum für Naturund Heimatkunde, Magdeburg. Dr. G. A. Boulenger is the only previously elected honorary foreign member.

\section{Systematics in Relation to General Biology}

WHILE taxonomy has, in the past, been based mainly on morphology, the advances of the past two decades in cytology, ecology, genetics and other branches of biology have made it necessary to consider their contribution to the subject. As a result of meetings of members of the staffs of the John Innes Horticultural Institution and the Royal Botanic Gardens, Kew, and of zoologists interested in taxonomy, a "Committee on Systematics in Relation to General Biology" has been formed, the first open meeting of which will be beld in the rooms of the Linnean Society, Burlington House, London, W.1, on June 25 at 3 p.m. All biologists interested in the general aims of the Committee are invited to attend. The chairman of the Committee is Dr. Julian S. Huxley, and the two secretaries are Mr. J. S. L. Gilmour, Royal Botanic Gardens, Kew (botany), and Mr. H. W. Parker, British Museum (Natural History), South Kensington, S.W.7 (zoology).

\section{U.S. National Academy: New Members}

THe following have recently been elected members of the U.S. National Academy of Sciences: Dr. C. B. Bridges, geneticist at the California Institute of Technology; Dr. O. E. Buckley, assistant director of research in the Bell Telephone Laboratories; Prof. A. J. Dempster, professor of physics in the University of Chicago; Prof. E. W. Goodpasture, professor of pathology in Vanderbilt University; Dr. C. G. Hartman, research associate in the Depart. ment of Embryology, Carnegie Institution of Washington : Dr. D. F. Hewett, U.S. Geological Survey ; Prof. Leo Loeb, professor of comparative pathology in Washington University (St. Louis); Dr. D. A. MacInnes, associate member (physical chemistry) in the Rockefeller Institute for Medical Research; Dr. G. R. Minot, Boston City Hospital ; Prof. J. von Neumann, professor of mathematical physics in the Institute for Advanced Study, Princeton; Dr. S. B. Nicholson, astronomer at Mt. Wilson Observatory; Prof. Otto Struve, director of Yerkes Observatory; Dr. F. B. Sumner, professor of biology in the Scripps Institution of Oceanography; Dr. Charles Thom, soil microbiologist in the U.S. Department of Agriculture, and Prof. E. C. Tolman, professor of psychology in the University of California. Prof. August Krogh, of the University of Copenhagen, known for his work in animal physiology, has been elected as a foreign associate of the Academy.

\section{Announcements}

Dr. W. L. Burgess, Dr. W. R. Wooldridge, Sir Louis J. Kershaw and Sir Joseph Barcroft have been appointed members of the committee set up in November 1936 to review the facilities available for veterinary education in Great Britain (see Nature, 138, 837; 1936). Dr. Thomas Loveday, vicechancellor of the University of Bristol, has been appointed chairman.

Prof. James Young, director of the Department of Obstetrics and Gynæcology at the British PostGraduate School, has been elected chairman of the Medical Advisory Board of the British Social Hygiene Council in succession to Sir Farquhar Buzzard.

Prof. Wladimir Köppen, the eminent Graz meteorologist, has been awarded the shield of nobility by the German Chancellor.

Dr. Richard Hess, professor of zoology at the University of Berlin, has been made an honorary member of the Bavarian Academy of Sciences.

THe British Homœopathic Congress will be held at the Iangham Hotel, London, W.1. on June 17-18. Further information can be obtained from the Secretary, 69 Elizabeth Street, S.W.1.

The Fourth General Assembly of the International Union for the Scientific Investigation of Population Problems will meet in Paris on July 28 in connexion with the International Population Congress, organized by the French National Committee, which takes place on July 29-August 1. 